\title{
The link between corporate social performance and financial performance: empirical evidence from Japanese firms
}

\author{
Megumi Suto and Hitoshi Takehara* \\ Graduate School of Finance, Accounting and Law, \\ Waseda University, \\ 1-4-1 Nihombashi, Chuo-ku, Tokyo 103-0027, Japan \\ Email: megumi.suto@waseda.jp \\ Email: takehara@waseda.jp \\ *Corresponding author
}

\begin{abstract}
Since the globalisation of business and stock ownership in the 2000s, Japanese firms' relationships with shareholders and the policies related to corporate social responsibility (CSR) have significantly changed. This study adopts a stakeholder relationship approach to examining these changes and investigates the channels that link corporate social performance (CSP) and corporate financial performance (CFP) in the Japanese context. We found that the composite measure of CSP and a large part of dimensional CSP are significantly negatively related to all risk measures employed in this study. With respect to dimensional CSP, it is remarkable that environment and social contribution showed a strong negative relationship with market-based risk measures. However, the effects of CSP on profitability are mixed, and only the employee relationship is positively associated with profitability measures. These findings suggest that risk reduction through CSR activities holds more significance in creating long-term value for Japanese firms.
\end{abstract}

Keywords: corporate social responsibility; CSR; corporate social performance; CSP; corporate financial performance; CFP; stakeholder relations; Japan.

Reference to this paper should be made as follows: Suto, M. and Takehara, H. (2016) 'The link between corporate social performance and financial performance: empirical evidence from Japanese firms', Int. J. Corporate Strategy and Social Responsibility, Vol. 1, No. 1, pp.4-25.

Biographical notes: Megumi Suto is a Professor of Finance at Graduate School of Finance, Accounting and Law, Waseda University. She received her Doctorate in Economics from Keio University. Her principal research interests are corporate governance, corporate social responsibility, and financial systems.

Hitoshi Takehara is a Professor of Finance at Graduate School of Finance, Accounting and Law, Waseda University. He received his $\mathrm{PhD}$ in Management Science and Engineering from the University of Tsukuba. His principal research interests are asset pricing, portfolio management, and positive accounting. 
This paper is a revised and expanded version of a paper entitled 'The impact of corporate social performance on financial performance: evidence from Japan' presented at the 21st Annual Meeting of the Nippon Finance Association, Hitotsubashi University, Tokyo, Japan, 1-2 June 2013 and 22nd International Business Research Conference, Hotel Melia Galgos, Madrid, Spain, 9-10 September 2013.

\section{Introduction}

Corporate social responsibility (CSR) has become a core concept in corporate management, particularly for companies with operations affected by globalisation and increasing institutional ownership. The proposition that corporations have some responsibility in promoting societal benefits and the preservation of the natural environment is widely accepted. Activities related to CSR can be narrow in scope (i.e., developing CSR-friendly corporate strategies); however, the broad management of social issues represents fundamental CSR. The importance and ubiquity of CSR imply that corporate social performance (CSP), which is a measure of a corporation's efforts and achievements towards social responsibility, concerns researchers and practitioners. CSP measures the extent to which corporations practically handle their social responsibilities.

The main purpose of this study is to explore the channels linking CSP to corporate financial performance (CFP) in Japanese firms in the late 2000s based on the stakeholder approach. They are conventionally categorised as insider systems or relationship-based systems, but are transitioning towards more outsider-oriented and market-oriented systems. It is an interesting research agenda to investigate CSP-CFP links within Japanese firms compared to the western counterparts. To explore the CSP-CFP link, we examine corporate managers' motivation for implementing and sustaining CSR-related practices in terms of enhancing profitability and/or reduction risks. Using five dimensional CSP indices related to stakeholder relations [e.g., employee relations (EMP), environmental preservation (ENV), social contributions (SCs), product quality, and internal governance] and a composite CSP measure, we tested two hypotheses (i.e., the competitive advantage hypothesis and the risk reduction hypothesis) to reveal the interdependence of CSP and CFP. Our empirical results partially support the competitive advantage hypothesis and strongly support the risk-reduction hypothesis. The findings show that risk reduction through CSR activities is more important than profitability enhancement in creating long-term firm value in the context of Japanese firms.

The rest of this paper proceeds as follows: Section 2 surveys extant research on the relationships between CSP and CFP and emphasises recent work that highlights the channels that link CSP and CFP. Section 3 presents research objectives and proposes testable hypotheses. Section 4 explains the methods employed in the data construction and model estimation. Section 5 presents the results of our analyses. In Section 6, we discuss implications for the development of CSR practices in Japanese firms and provide avenues for future research. 


\section{Literature review}

\subsection{The relationship between CSP and CFP}

To ensure their long-term survival in a competitive business environment, many firms have increasingly allocated their resources to CSR practices in response to stakeholder requests. Academics and business professionals have engaged in debate on the relationship between CFP and CSP since the 1970s (see Orlitzky et al., 2003; Van Beurden and Gossling, 2008). For businesses, the influence of CSP on CFP is critically important because it affects their ability to fulfil responsibilities to their shareholders. However, firms that are small or unstable face greater difficulty in using corporate resources to engage in CSR activities. Therefore, the determinants and interdependence of CFP and CSP are serious considerations for corporate managers.

CSR relates to a wide range of business activities, processes, and outcomes. Thus, costs and benefits of activities related to CSR are diverse and multi-dimensional. Illustrating the complexity associated with implementing CSR activities in firms, there are often conflicts between shareholders and other stakeholders regarding the ways in which CSR is operationalised. Agency theory focuses on additional costs driven from the conflicts under information asymmetry. Alternatively, stakeholder theory argues that stakeholder management to mitigate conflicts between stakeholders determines organisational efficiency, reduction of risk, and the long-term success of the firm (e.g., Surroca et al., 2010). CSR practices to adapt to changing social and environmental demands are rewarded for meeting the expectations of shareholders (Carroll and Shabana, 2010). Stakeholder relations can be a source of competitive advantage. However, managerial decisions that are made without consideration for stakeholder concerns may increase business risk by damaging employees' motivation, the quality of products, the firm's reputation, or clients' trust. Therefore, effective stakeholder management reduces the uncertainty of future business and decreases financial market risk (e.g., Salama et al., 2011).

The amount of empirical research exploring the link between CFP and CSP has been extensive, but inconclusive. However, the majority of studies identify a positive relationship between CSP and CFP as investigated by meta-analyses (Orlitzky et al., 2003; Van Beurden and Gossling, 2008). Orlitzky et al. (2003) suggest that CSP is more highly correlated with accounting-based measures of CFP than market-based measures. Other research in this area has focused on risk reduction by CSR practices. Early studies show that investors perceive socially responsible firms as low risk with respect to investment (Orlitzky and Benjamine, 2001). More recent research also indicates a negative relationship between CSP and market-based risk (Boutin-Dufresne and Savaria, 2004; Gregory et al., 2014; Mishra and Modi, 2013; Salama et al., 2011). Other research highlights the influence of CSR on costs of capital (Ghoul et al., 2011; Goss and Roberts, 2011).

Given the inconclusive nature of the existing studies, the relationship between stakeholder management and profitability/risk represents an interesting research topic.

\subsection{Mechanisms and channels to link CSP and CFP}

Prior research has suggested that CSP is linked to long-term corporate value. However, the case for engaging in activities related to CSR to achieve business-related goals 
remains a topic of great debate. One reason for the continued debate relates to the variety of ways in which CSR is defined and operationalised. CSP is a multi-faceted concept that incorporates stakeholder management, social issues management, and ENV. Therefore, CSP measures are traditionally multi-dimensional and less definitive.

Another reason for the continued confusion surrounding the relationship between CSP and CFP is the channels that link CSR activities with financial performance. Operationally, stakeholder management is based on these channels. Although firm stakeholders absorb the costs and risks associated with a firm's attempts to generate corporate value, those same stakeholders do not necessarily enjoy the benefits derived and distributed from firm activities. For example, Scholtens and Zhou (2008) find trade-off between shareholder and stakeholder interests. Strategic stakeholder management is a vital component for the efficient creation of long-term firm value (Jensen, 2001).

Perrini et al. (2011) provide a stakeholder-based organising framework to identify antecedents and outcomes of the CSP-CFP relationship. The stakeholder approach extricates the precipitants of the CSP-CFP relationship and the channels linking CSR and financial performance. The approach induces responsible manager behaviours by highlighting the motivations of different stakeholders and channels such as innovation, human resources, reputation, and trust (Surroca et al., 2010).

Of the various CSR-related organisational drivers, human resource management is most significant in inciting productivity and innovation among employees (Turban and Greening, 1997). CSR initiatives in the consumer market can boost a firm's reputation (Schuler and Cording, 2006; Smith, 2008). Corporate strategy with respect to the management of business and the natural environment has been a subject of research since the 1990s (Hart, 1995; Jiao, 2010; Russo and Fouts, 1997). Disclosure of CSR-related information affects corporate value through brand positioning, and supply-chain management is critical for the success of a firm's cross-boundary business endeavours (Wolf, 2014). Thus, the social and environmental aspects of management have become increasingly important channels for CSR practices.

\section{Hypotheses development}

As discussed in Section 2, previous research concerning responsible management shows that CSR has various attributes (or dimensions) that affect the motivation of various stakeholders and financial performance. The development of effective CSR policies, however, is contingent upon the extent to which managers are motivated to implement those policies (Goss and Roberts, 2011). The boosting of manager motivation toward the development and operationalisation of CSR is critical to gain market-based competitive advantage in profit-making and in mitigating risks in future business.

Some perceive that typical Japanese corporations exercise ethically questionable self-regulation and succession practices within an insider-oriented system and relationship-based system. However, traditional Japanese firms are widely considered to engage in several socially responsible activities (e.g., high quality product development, SCs, and providing community employment) to sustain their businesses over time. Such activities have provided Japan with more companies remaining operational for over one hundred years than any other country in the world. ${ }^{1}$ The maintenance of trust among 
customers to sustain public confidence is a common characteristic among these firms. With respect to business globalisation and changes in social and environmental circumstances surrounding business, however, Japanese firms must review their shareholder relations and stakeholder management. By considering the interests of the different stakeholders, firms become sustainable and gain various competitive advantages within the market.

From the perspective of competitive advantage, CSR dimensions are linked to the individual sources of firm profitability. CSR practices incentivise employees, improve the quality of products and increase their demand, promote exploration for new business opportunities that meet social demands, and conserve energy and resources in the production process. Each individual dimension of the index may positively influence a firm's financial performance. Therefore, a composite CSP index that integrates different CSR dimensions would positively influence profitability and long-term corporate growth.

Hypothesis 1 (H1) A positive relationship exists between CSP and a firm's profitability.

If managers consider CSR practices tools for managing corporate risk, CSP would negatively affect the perceptions of accounting-based risks and reduce uncertainty concerning future business development. The composite CSP index would also negatively influence market-based risk by promoting greater trust within the market. With respect to the individual CSR attributes, the CSP of various corporate divisions may reduce uncertainty associated with stakeholder behaviour and thus reduce the risks associated with conducting business. However, the risk structure may vary as a function of a firm's industry or developmental stage. Therefore, the respective relationships between the individual CSP attributes and CFP may also vary, even if CSR-related activities affect CFP cumulatively.

Hypothesis 2 (H2) A negative relationship exists between CSP and risk.

\section{Data and research methodologies}

\subsection{Measures of CSP}

To measure CSP, we use the CSP database constructed by Suto and Takehara (2014) that highlights the five most important stakeholders for Japanese firms. ${ }^{2}$ These stakeholders are employees, the natural environment, society and communities, consumers and suppliers, and shareholders and debt holders. The authors' classification of stakeholders is consistent with the Girerd-Potin et al. (2014) typology: business stakeholders (employee, customers, and suppliers), social stakeholders (the environment and society), and financial stakeholders (stockholders and debt holders). The classification is also consistent with Clarkson's (1995) classification of primary stakeholders including shareholders and investors, employees, suppliers, government, and communities with the exception of the environment. Suto and Takehara (2014) construct CSP dimensional indices that correspond to the five most important stakeholders.

The first dimension, $E M P$, represents organisational working conditions, appropriate working hours and salary, the employment of minorities, job stability, and opportunities 
for employees' personal and vocational development. The effective management of EMP can thus increase employee motivation and improve the quality of their output.

The second dimension, $E N V$, is a critical aspect of CSR in a society that has grown increasingly concerned with global climate change. Many perceive ENV to be the principle social responsibility of firms, a method of gaining trust and a desirable reputation in society, and a source of energy saving innovation.

The third dimension, SCs, represents a firm's policies and response with respect to social demands. Positive relationships and effective coordination with the community in which the firm operates can reduce costs associated with local conflicts, attract effective human resources, and enhance the firm's reputation. In contrast, negative relationships with the surrounding community can restrict business opportunities and increase the costs and risks associated with established business operations.

The fourth dimension, firm security and product safety (SS), represents the quality of a firm's products and the sustainability of its business. Therefore, the promotion of SS can provide a firm with long-term competitive advantages. Security and safety affects supply chain management and the firm's activities and ultimately influences the trust of customers and firm reputation in the markets. Thus, SS also contributes to risk mitigation.

The fifth dimension, internal governance and risk management (IG), represents the demonstrable quality of a firm's disclosure, compliance, internal auditing, and self-discipline with respect to CSR. This dimension is directly linked to a firm's relationship with financial stakeholders and contributes to financial market perceptions of firm CSR. Firm internal governance is structured according to the regulatory and legal framework of the society. Firms must choose appropriate internal governance architecture and adopt strategies within the existing regulatory framework.

Suto and Takehara (2014) constructed the CSP indices related to the above five dimensions using the Toyo Keizai CSR database as a primary data source. Because the CSR data are based on survey responses from the year 2007 to the year $2011^{3}$, this period forms the temporal basis for our study. The original database consists of three parts: EMP (Part 1), an overall survey-related CSR (Part 2), and ENV (Part 3). Then, the authors subdivided Part 2 into three distinct CSR dimensions, which correspond to the stakeholder relations we chose.

First, the authors selected 17 questions related to EMP, 21 questions concerning CSR in a general sense, and 18 questions regarding ENV. For each of the five CSP attributes, we used a principal component analysis to construct CSP dimensional indices. Then, on the basis of responses to the questions that Suto and Takehara (2014) selected, the authors kept 13 scores regarding EMP, five scores regarding SCs, five scores regarding security of the firm and product safeness (SS), six scores regarding internal governance and risk management (IG), and five scores regarding ENV. The item scores and their related factor loadings are shown in Table A1.

The authors then demeaned and scaled each CSP dimensional index by its standard deviation so that it approximately obeyed a standard normal distribution. Finally, the authors computed the composite CSP index based on the five dimensional indices described above. Let $r$ ( ) denote the function that gives a rank of the element of the vector in ascending order and $n$ denote the number of firms in each year. Given this, the comprehensive measure of CSP in each year is defined as follows: 


$$
C S P=\frac{r(r(E M P)+r(S C)+r(S S)+r(I G)+r(E N V))-1}{n-1} \times 6-3
$$

It is convenient for researchers if the scale of the composite CSP measure is comparable to those of the CSP dimensional indices. Because our CSP dimensional indices approximately obey a standard normal distribution, equation (1) was adjusted such that the composite measure of CSP is uniformly distributed and falls in the interval $[-3,3]$.

\subsection{Profitability and risk measures}

Most previous research has examined the relationship between CSP and profitability measures such as return on equity (ROE) and return on assets (ROA), which are computed based on accounting information that reflect internal decision-making capabilities and managerial performance (Orlitzky et al., 2003; Orlitzky, 2008). However, these conventional measures for profitability capture only one part of a firm's financial performance. To address this shortcoming in the literature, this study employs three types of profitability measures. The first measure is based on accounting information and is composed of return on sales (ROS), ROE, ROA, and the ratio of cash flows from operations to total assets (CFOTA). We also use CFOTA to account for the possibility that managers manipulate net income (a numerator of the ROS, ROE, and ROA ratios), and because cash flow from operations is less manipulated by managers (Orlitzky and Benjamin, 2001).

The second type of profitability measure is the growth potential of the firm. These measures include the growth rate of sales (GSLS) and the growth rate of total assets (GTA). The third type of profitability measure is computed based on realised stock returns. Specifically, we compute the historical return (HRET) and Jensen's alpha (alpha) based on the following Fama and French's (1993) three-factor model (2).

$$
r_{j t}-r_{f t}=\alpha_{j}+\beta_{j}^{V W}\left(r_{m t}-r_{f t}\right)+\beta_{j}^{S M B} S M B_{t}+\beta_{j}^{H M L} H M L_{t}+\varepsilon_{j t} .
$$

In model (2), $r_{j t}$ is a return of $j^{\text {th }}$ stock in month $t, r_{f t}$ is a risk-free rate in month $t, r_{m t}$ is a market value-weighted return of stocks listed in the Tokyo Stock Exchange (TSE) first and second sections, and $S M B_{t}$ and $H M L_{t}$ are the small-minus-big and high-minus-low factors, respectively. We use this model because standard capital asset pricing models (CAPM) cannot explain the cross-sectional return variation of Japanese stocks. ${ }^{4}$

Because ROS, ROE, ROA, CFOTA, GSLS, GTA, HRET, and Alpha fluctuate annually, we compute the average of these measures over the past five years to examine the relationship between CSP and CFP in the long-term. ${ }^{5}$

Extant literature on the relationship between CSP and CFP often lacks consideration of the ways in which CSP affects corporate risk. However, we expect that effective CSP will reduce a firm's risk and examine the risk-reduction hypothesis (H2). Therefore, in addition to the profitability measures, we also employ risk measures. Each of these risk measures corresponds to one of the eight outlined profitability measures. To examine the relationship between CSP and the risks faced by a firm, we compute the standard deviations for ROS, ROE, ROA CFO, GSLS, and GTA. We also compute the five-year historical volatility of stock returns (HVOL) and the standard deviation of residual volatility over the previous five years (Omega). 
The definitions of profitability and risk measures used in this study are summarised in Table A2.

\subsection{Control and instrument variables}

In the regression model employed in this study, we additionally use three control variables. First, many studies have found a positive association between a firm's CSP and its size. Firm size is identified as a confronting variable for CSP and CFP association in general (Van Beurden and Gossling, 2008). We use the natural logarithm of total asset value (in millions of Japanese yen), lnTA, as a proxy for firm size. Because the association between CSP and size is nonlinear, we employ size dummy variables: Size2 for mid-size firms and Size3 for small-size firms. We select two other control variables, firms' debt ratio (DR) and a foreign dependency ratio (FDR). Debt dependency influences risk as well as potential profitability. Effective CSR activities will alleviate the agency conflicts between debt holders and other stakeholders. Relationships with foreign stakeholders have been increasingly important for financial performance of Japanese firms. Managers must ensure high quality customer service globally; a task facilitated by superior CSP. DR is defined as total debt divided by total assets, and FDR is defined as foreign sales divided by total sales.

In addition to the control variables, we employ two instrument variables into our analyses: lagged one-year CSP indices and Amihud's (2002) illiquidity measure (ILLIQ). Lagged values of CSP indices are used as instrument variables in Schreck (2011), and they may fulfil prerequisites of instrumental relevance and exogeneity. The purpose of introducing these instruments is to control endogeneity resulting from reverse causality from CFP to CSP.

\subsection{Samples}

We use the CSP database developed by Suto and Takehara (2014). The sampling period spans five years, from 2007 to 2011, and the database includes all of the Japanese firms that responded to the questionnaire survey administered by Toyo Keizai Incorporated. ${ }^{6}$ Because Toyo Keizai Incorporated sent the questionnaires to the firms in the beginning of July and the firms provided their answers by the end of September, we use the most recent consolidated financial statement data and market attributed data that were available at the end of September. All financial firms are excluded from our sample. The primary source for financial statement data is the NIKKEI NEEDS Database. Market-attributed data are taken from the FDS-NPM Database. The total number of firmyears for the sample is 3,564.

Table 1 summarises the firm sample used in this study, delineated by year and corporate sector. $^{7}$ Approximately $70 \%$ of the sampled firms are listed in the First Section of the TSE, approximately $10 \%$ of the firms are listed in the second section of the TSE, and approximately $20 \%$ of firms are listed in exchanges other than the first or second sections of the TSE. The investment goods sector was the most heavily represented sector among sample firms (40\%), and over $75 \%$ of firms from this sector are listed in the first section of the TSE. 
Table 1 Number of sample firms

\begin{tabular}{lccccccccc}
\hline Sector & 2007 & 2008 & 2009 & 2010 & 2011 & TSE1 & TSE2 & Others & Total \\
\hline $\begin{array}{l}\text { Consumption } \\
\text { goods }\end{array}$ & 173 & 168 & 171 & 185 & 187 & 180 & 25 & 40 & 245 \\
$\begin{array}{l}\text { Investment } \\
\text { goods }\end{array}$ & 268 & 281 & 291 & 297 & 291 & 284 & 39 & 65 & 386 \\
Services & 168 & 166 & 202 & 216 & 235 & 186 & 33 & 101 & 314 \\
Transportation & 19 & 20 & 19 & 21 & 24 & 21 & 2 & 4 & 27 \\
Utility & 10 & 11 & 11 & 13 & 11 & 13 & 0 & 0 & 13 \\
Real state & 21 & 25 & 19 & 20 & 21 & 22 & 5 & 8 & 35 \\
\hline All sectors & 659 & 671 & 713 & 752 & 769 & 706 & 104 & 218 & 1,020 \\
\hline
\end{tabular}

Notes: Number of firms listed on Tokyo Stock Exchange 1st section (TSE1), on Tokyo

Stock Exchange second section (TSE2), and other stock exchanges in Japan (others) are reported here. Firms listed in the four right-most columns are not duplicated, and a single firm can be counted a maximum of four times in our sample period.

\subsection{Methodologies}

To explore the extent to which CSP influences CFP, we first employ the portfolio formation method. At the end of September of each year $(t=2007$ to 2011), we split the sample into quintiles by ranking the composite CSP scores. We then test for differences in CSP between the higher and lower quintiles of each CSP level. We employ a portfolio formation approach and confirm whether a statistically or economically significant dispersion of CSP exists among the sample firms. Portfolio formation also facilitates the examination of the adequacy of the linearity assumption between CSP and CFP. If a nonlinear relationship is found between CSP and CFP, we cannot investigate the impact of CSP on CFP by running linear regression analysis. The portfolio formation method can highlight the characteristics of the data and has become a standard tool in empirical studies.

Next, we conduct a two-stage linear regression analysis. Regression analysis is essential to verify the robustness of our findings from the portfolio formation approach because we cannot control several characteristics of the firm simultaneously. Through regression analysis, we confirm whether the dispersion of CFP between high-CSP firms and low-CSP firms remains after controlling for factors such as firm size, capital structure, and industry. We employed the following regression model after controlling for firms' individual characteristics:

$$
\begin{aligned}
y_{j, t}=\alpha & +\beta x_{j, t}+\gamma_{1} D_{j, t}+\gamma_{2} \text { FDR }_{j, t}+\sum_{i=1}^{2} \delta_{i} \text { DSize }_{i+1, j, t} \\
& +\sum_{i=1}^{5} \lambda_{i} \text { DSector }_{i+1, j, t}+\sum_{t=2008}^{2010} \eta_{t-2007} \text { DYear }_{j, t}+\varepsilon_{j, t} .
\end{aligned}
$$

In model (3), $x_{j, t}$ represents a composite measure for CSP or one of five CSP dimensional indices for the firm $j$ in year $t$. Explained variable $y_{j, t}$ represents either the profitability or risk measure for the firm. DSize $_{i, j, t}$ is a dummy variable, which equals 1 if the sample $j$ belongs to the $i^{\text {th }}$ size ranked portfolio in year $t$ and 0 otherwise. DSector ${ }_{i, j, t}$ is a dummy 
variable that equals 1 if the sample $j$ belongs to the $i^{\text {th }}$ sector and 0 otherwise. ${ }^{8}$ Finally, DYear ${ }_{j, t}$ are the dummy variables for each year (i.e., $\left.t=2008,2009,2010\right){ }^{9}$

The possibility exists that the CSP variables in regression model (3) are correlated with the error term through reverse causality (i.e., financial performance may actually determine the extent to which firms engage in CSP of the firms). To mitigate the endogeneity problem that would result from this, we employ a two-stage least squares regression model. We add two instrument variables (lagged one-year CSP variables and Amihud's ILLIQ) in the first stage, which we expect to be less correlated with the error terms of the dependent variables in the original regression equations. ${ }^{10}$

\section{Results and implications}

\subsection{Correlations between CSP and CFP}

Before the portfolio formation and regression analysis, we simply examine the correlations between the CSP and CFP measures. Table 2 shows the Spearman rank correlations and corresponding statistical significances. Table 2 shows that composite CSP (CSP), EMP, environment (ENV), and SC are positively correlated with eight profitability measures and are significant at the $1 \%$ level in most cases. Similarly, the correlations between the security of the firm and product safety (SS) and the various profitability measures are positive and significant at the $5 \%$ level except GSLS. Although internal governance and risk management (IG) is positively associated with multiple metrics for profitability, it is not significantly correlated with market-based profitability measures (HRET and Alpha) at the 5\% level. These findings provide confirmatory evidence for the competitive advantage hypothesis (H1).

In contrast to the relationships with the profitability measures, most CSP dimensional indices are significantly and negatively correlated with the measures for corporate risk. For example, CSP, EMP, and ENV are negatively correlated with risk measures at the $5 \%$ level, except the correlation between EMP and GSLSSD. Regarding SC and SS, correlations with risk variables are all negative, although some cases are not significant. Contrary to our expectation, the correlations between internal governance and risk management (IG) and accounting-based risk metrics are positive but not significant. IG is negatively correlated with the market-based risk measures HVOL and Omega. However, only Omega is statistically significant.

These results support the risk reduction hypothesis (H2). A firm's engagement in effective CSR may reduce risk.

\subsection{Differences in financial performance: high and low CSP portfolios}

For each year (2007 to 2011), sample firms are ranked based on their composite CSP scores, and five portfolios are constructed. P1 is a portfolio containing firms with a CSP score in the top $20 \%$ of the overall sample, and P5 is a portfolio containing firms with a CSP score in the bottom $20 \%$ of the overall sample. Table 3 shows profitability and risk measures of these five portfolios ranked by composite CSP. The column labelled 'Difference' reports the average CSP difference between P1 and P5, and the column labelled ' $p$-value' denotes the corresponding probability values from Welch's two-sample t-test. 
Table 2 Spearman rank correlation between CFP and explanatory variables

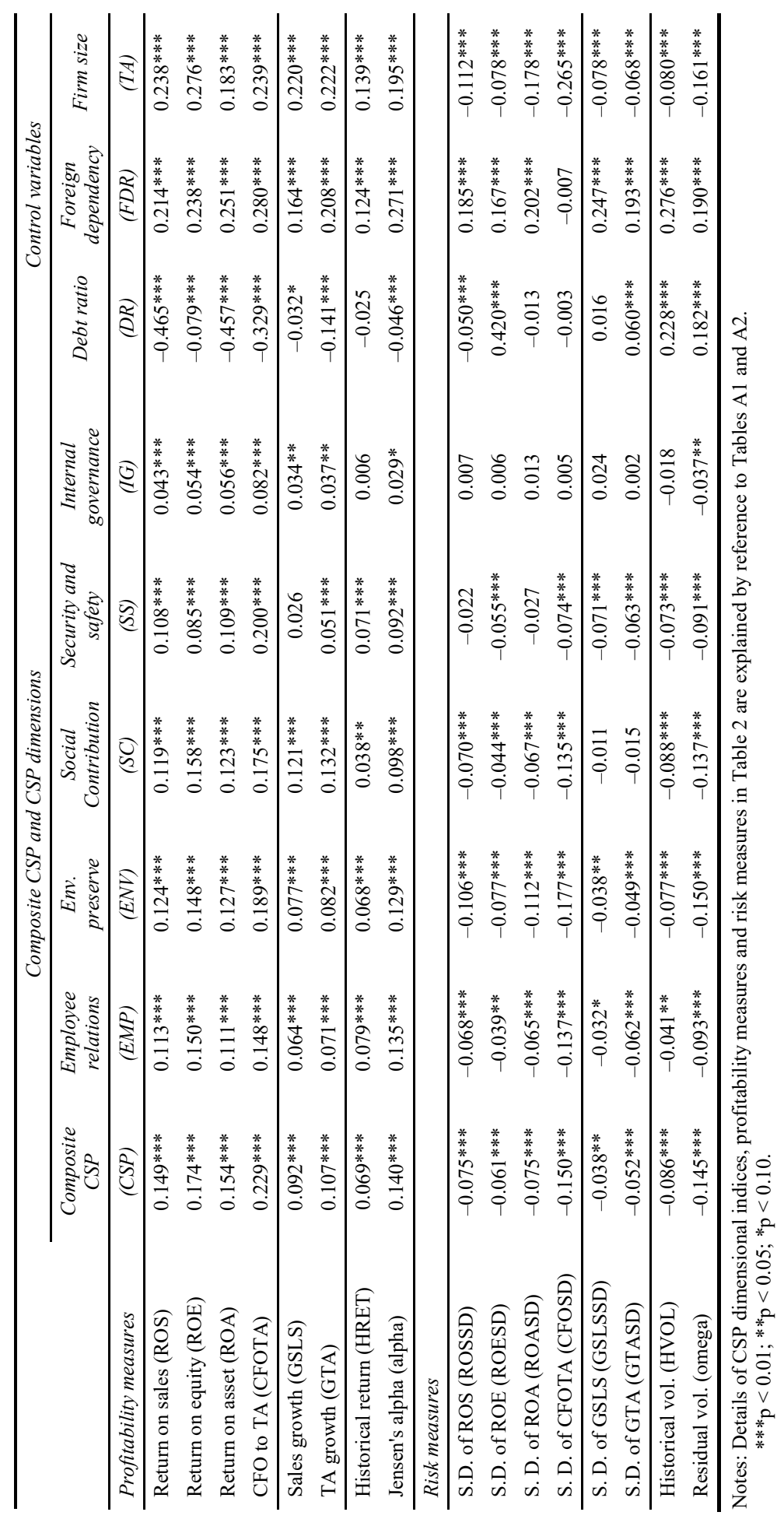


Table 3 CFP of composite CSP ranked portfolios

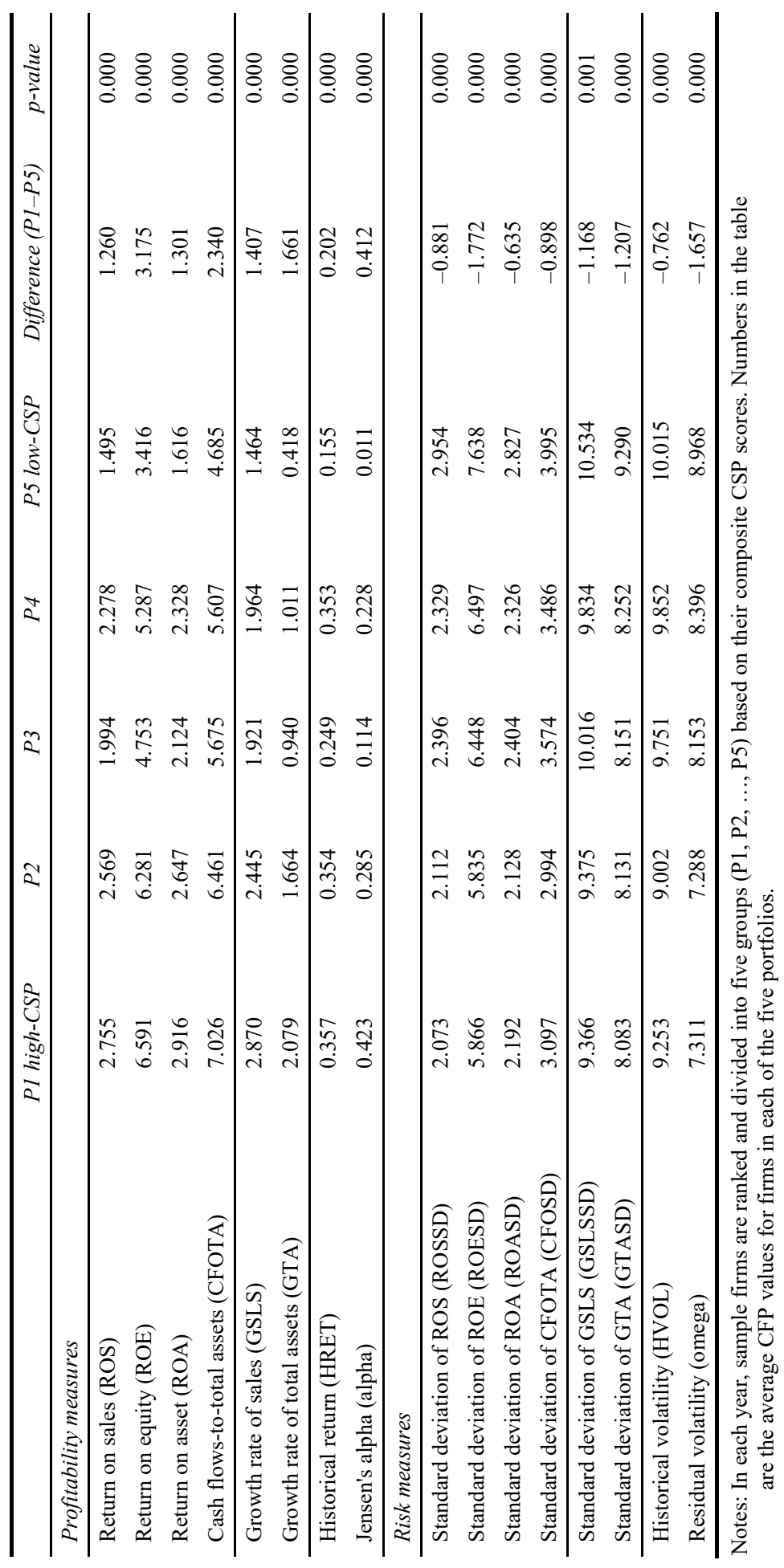


The profitability measures tend to increase as a function of CSP as a whole, although there is slight unevenness at the middle-level CSP portfolio P3. The differences between the average profitability measures for firms in P1 and P5 are significantly different $(p<0.01)$. In contrast, the risk measures tend to decrease as a function of composite CSP as a whole also, although there is slight unevenness at P4. The differences between firms in P1 and P5 are also significant $(p<0.01)$. Therefore, the results reported in Table 3 support both the competitive advantage hypothesis $(\mathrm{H} 1)$ and the risk reduction hypothesis (H2).

From the results reported in Table 3, we confirm that the relationships between CSP and profitability and risk measures are nearly monotone and linear. Thus, we can safely examine the linear model using two-stage least squares regressions.

\subsection{The regression results}

We use one-year lagged CSP variables as instrument variables; therefore, we use four years of data (2008 to 2011) in the following two-stage least squares regression analysis. The number of firm-year observations in this panel data is $2,905 .{ }^{11}$

Table 4 reports the results from the two-stage least squares regression analysis that includes two control variables (DR and FDR), two size dummies, five sector dummies, and three year dummies to evaluate the effects of composite CSP on CFPs. To conserve space, we do not include the coefficients associated with the dummies. In Table 4, Panel A presents the results of a regression in which profitability measures are used as dependent variables, and Panel B presents the results of equivalent analyses in which risk measures are used as the dependent variables. ${ }^{12}$

Panel A shows that the results of the analyses designed to ascertain the effect of composite CSP on profitability are mixed. Composite CSP is not significantly and positively related to any profitability measures except cash flow (CFOTA). Further complicating the results, composite CSP is negatively associated with four measures, ROS, GSLS, GTA, and HRET, although only the result of GSLS is statistically significant. Whereas cash flows from operations indicate profitability before accruals based on earning management, profit on sales is sensitive to cyclical fluctuations. In the long run, CFOTA is a more stable measure of profitability than ROS.

Other accounting-based measures (i.e., ROE and ROA) and market-based measures (i.e., HRET and Alpha) are not significantly related to composite CSP. These findings are inconclusive and do not provide definitive support for the competitive advantage hypothesis (H1). However, if cash flow is associated with superior long-run growth prospects, as Gregory et al. (2014) emphasise, our results do not contradict the competitive advantage of the firm in the long run.

In contrast to the profitability measures, all measures for risk are significantly and negatively associated with composite CSP (see Panel B). This suggests that CSR practices are closely related with risk reduction, thus supporting the risk reduction hypothesis $(\mathrm{H} 2)$. 
Table 4 Regressing firms' profitability/risk measures onto composite CSP

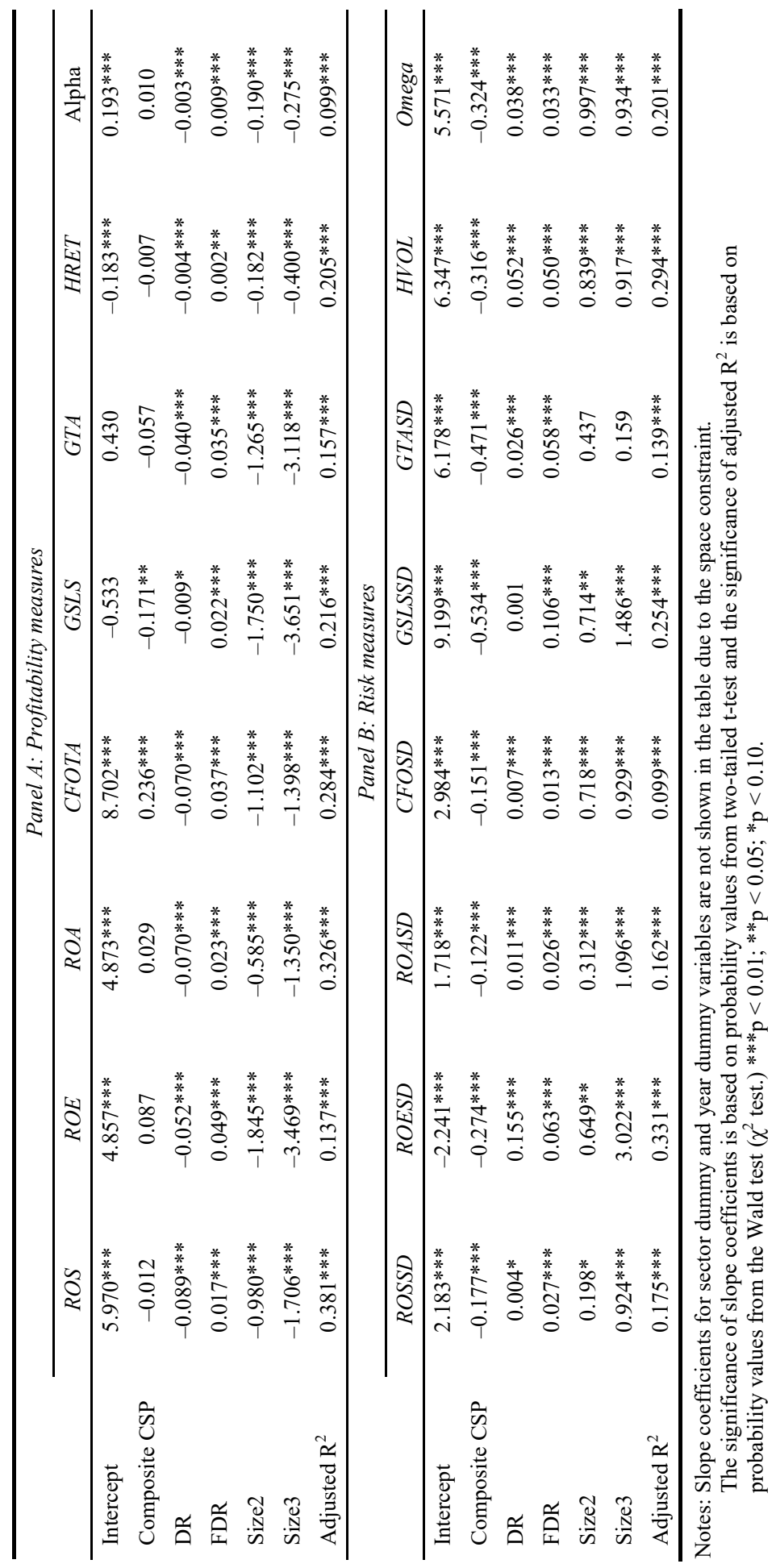


Table 5 Regressing firms' profitability/risk measures onto CSP dimensional indices

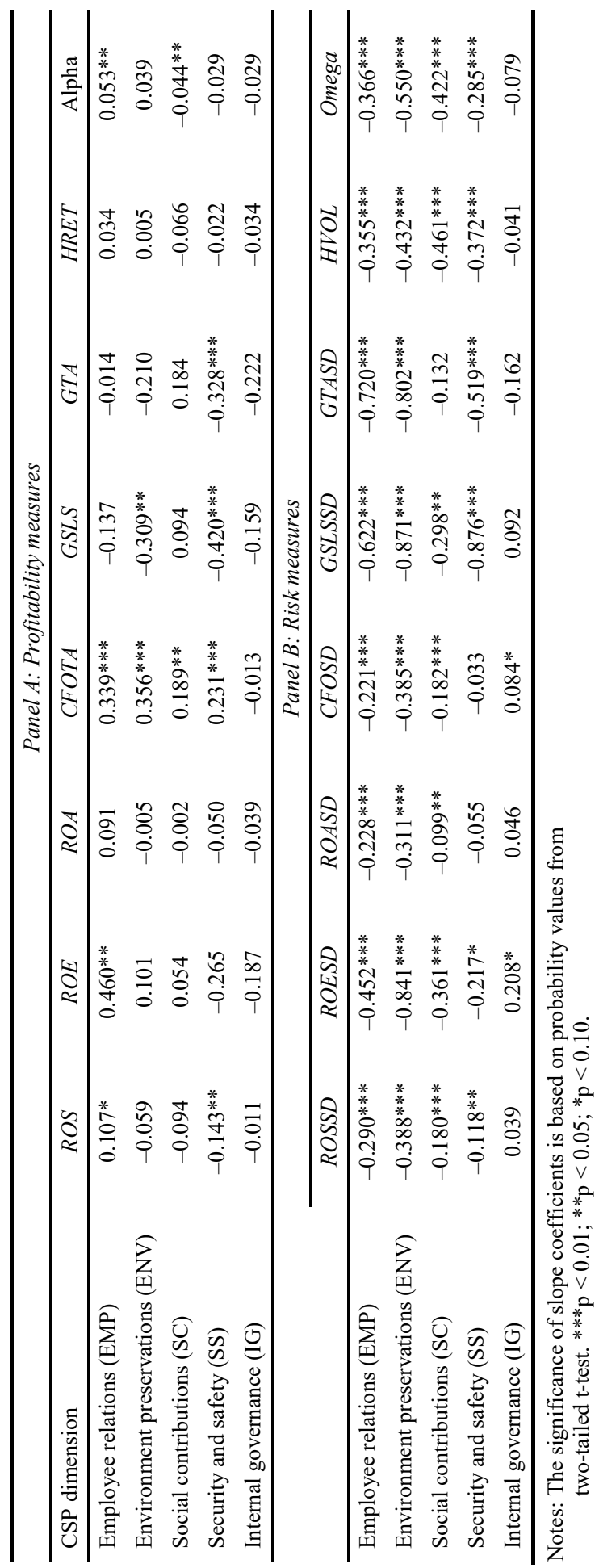


Within the results of the profitability measures and risk measures, our analyses reveal interesting results concerning corporate growth rates and volatility. Table 4 demonstrates that composite CSP is significantly and negatively related to sales growth (GSLS). CSP is also negatively related to growth in total assets (GTA), although the regression slope is not significant. These results suggest a trade-off between the extent to which a firm engages in CSR practices and its ability to grow. However, composite CSP is also negatively related to volatility for firm growth $(p<0.01$; see Table 4$)$. These results suggest that CSR practices require corporate resources (both financial and logistic) to secure future opportunities for growth although, in the long run, costs associated with CSR-related investment could be gradually mitigated by corporate profitability and growth.

Some of our control variables are significantly associated with CFP measures. Table 4 shows that DR is negatively related with the profitability measures and largely positively related with risk measures. As expected, FDR is positively associated with both profits and risk.

We also explored the respective effects of the index's individual components in addition to analysing the effect of the composite CSP index on various CFP measures. Table 5 shows the estimated slope coefficient for CSP dimensional indices and their significance. ${ }^{13}$ In Panel $\mathrm{A}$, the results on profitability measures are inconclusive. In Panel B, with the exception of internal governance (IG), most cases of CSP dimensions are negatively related with risk measures. This indicates a general tendency for a negative relationship between CSP and perceptions of firm risk. We confirm that the CSR risk reduction effects are robust for the Japanese listed firms. H2 is strongly supported. Because the results on profitability shown in Panel A are more inconclusive, detailed synopses are required to explain the respective influences of CSP components.

First, the EMP measure is positively related to all profitability measures except GSLS and GTA. EMP is significantly related to three accounting-based measures ROE and CFOTA $(p<0.01)$ and ROS $(p<0.10)$, and also to both HRET $(p<0.10)$ and Jensen's alpha $(p<0.05)$. Moreover, EMP is significantly and negatively associated with all risk-related measures $(p<0.01)$. Therefore, investors may consider EMP an indicator of risk associated with a given firm. Concerning EMP, both $\mathrm{H} 1$ and $\mathrm{H} 2$ are supported. We comprehend that EMP is a key component of intangible resources for Japanese firms.

Second, ENV is strongly associated with risk measures. Specifically, in most cases, the slope coefficients associated with the risk measures are more pronounced in models that account for ENV. We interpret the results to imply that social reputation and market perceptions are heavily contingent on a firm's ENV policies. Therefore, it is crucial for firms to engage in sound ENV practices to promote sustainability of the company, regardless of the short-term costs.

Third, SC is negatively related to market-based profitability measures, whereas SC is not significantly associated with accounting-based measures with the exception of CFOTA. SC is accompanied by short-term profit shifts although the societal benefits are sometimes ambiguous; SC can be perceived as contrary to shareholder benefits in the financial market. However, SC shows strong negative effects on market-based risk measures. We posit that SC-sensitive firms may be perceived as stable, mature firms with slack resources in the Japanese market.

Fourth, analyses of the effect of firm SS on a firm's accounting-based profitability show mixed results, but market-based profitability measures reveal insignificant and 
negative relationships. With respect to risk measures, all of the results are significantly negative except the standard deviation of ROA (ROASD) and the standard deviation of CFO (CFOSD). Product quality and safety are strongly linked to sustainability intermediated by reputation in the consumer market and trust in customer relationships.

Finally, the results of IG are unexpected but interesting. The results are mixed for all profitability measures. IG shows a negative but statistically insignificant relationship with profit measures. Moreover, a notable, positive association is found with accounting-based risk measures with the exception of the standard deviation of the growth rate of total assets (GTASD). The estimates of ROESD and CFOSD are statistically significant at the $10 \%$ level. The estimates of market-based risk measures are negative but insignificant. The results suggest that IG-related practices of Japanese firms do not function and may be spurious.

Therefore, in the context of Japanese CSR, the competitive advantage hypothesis (H1) is partially supported, and the risk reduction hypothesis (H2) is strongly supported. A comparison with prior studies' results for non-Japanese firms shows that CSR competitive advantage strategies are relatively weak in the Japanese context, with the exception of EMP. Considering similar findings in many prior studies on non-Japanese firms, EMP represent a significant contributor to profitability for firms worldwide.

\section{Conclusions}

In the Japanese firm context, the direct link between CSP and profitability measures seems weaker than the direct link between CSP and profitability compared to global counterparts in many prior studies. Three reasons may explain this. First, managers of Japanese firms are inclined to focus on business sustainability and to conduct CSR practices to promote firm reputation and trust rather than to develop them as sources of competitive advantage, as indicated in Section 3. Second, the stagnant economy since the end of the 1990s has caused Japanese investors to focus on short-term financial performance and to be less sensitive to CSR with respect to firm valuation for investees. Suto and Toshino (2005) find short-term behaviour bias in Japanese institutional investors. Third, Japanese investors' attitudes may have further shifted toward risk mitigation since the global financial crisis compared to the attitudes of global market investors. Lopatta and Kaspereit (2014) empirically reveal that capital market perceptions worldwide concerning sustainability have become more positive since the financial crisis of 2008. Further research development is required.

The results of this study provide practical implications for the CSR strategies of Japanese firms. First, managers who seek to fulfil social responsibilities can employ stakeholder management as a tool to mitigate business risk and may reduce risk in the financial market. Second, managers should actively explore intangibles related CSR as sources of profitability to compete in a global market. Third, managers should be conscious of market perceptions of firm CSR practices and should improve non-financial disclosure to moderate the perception gap with financial stakeholders.

Our study contributes to the extension research from a stakeholder management perspective concerning Japanese firms shifting from an insider orientation to a more market-oriented corporate system. The results imply that global firms, which share common social and environmental issues, should review their stakeholder management and explore intangible resources to adapt to a dynamic business culture. 
Finally, we address the limitations of this study. This study covers listed firms for the years 2007 to 2011 because of the availability of CSR data. An extension of the sample could explore the research perspective. The development of financial performance measures is another agenda for future research.

\section{Acknowledgements}

The authors acknowledge financial supports from the Health Labour Sciences Research Grant (Research on Policy Planning and Evaluation) and the Grant-in-Aid for Scientific Research (C) 26380481 from the Ministry of Education, Culture, Sports, Science and Technology of Japan.

\section{References}

Ajward, A.R. and Takehara, H. (2014) 'Does superior corporate social performance ease financial constraints of companies? The Japanese experience', Global Economy and Finance Journal, Vol. 7, No. 2, pp.42-58.

Amihud, Y. (2002) 'Illiquidity and stock returns: cross-section and time-series effects', Journal of Financial Markets, Vol. 5, No. 1, pp.31-56.

Boutin-Dufresne, F. and Savaria, P. (2004) 'Corporate social responsibility and financial risk', Journal of Investing, Vol. 13, No. 1, pp.57-66.

Carroll, A.B. and Shabana, K.M. (2010) 'The business case for corporate social responsibility: a review of concepts, research and practice', International Journal of Management Review, Vol. 12, No. 1, pp.85-105.

Clarkson, M.E. (1995) 'A stakeholder framework for analyzing and evaluating corporate social performance', Academy of Management Review, Vol. 20, No. 1, pp.92-117.

Fama, E.F. and French, K.R. (1992) 'The cross-section of expected stock returns', Journal of Finance, Vol. 47, No. 2, pp.427-465.

Fama, E.F. and French, K.R. (1993) 'Common risk factors in the returns on stocks and bonds', Journal of Financial Economics, Vol. 33, No. 1, pp.3-56.

Ghoul, S.E., Guedhami, O., Kwok, C.Y. and Mishra, D.R. (2011) 'Does corporate social responsibility affect the cost of capital?', Journal of Banking and Finance, Vol. 35, No. 9, pp.2388-2406.

Girerd-Potin, I., Jimenez-Garces, S. and Louvet, P. (2014) 'Which dimensions of social responsibility concern financial investors?', Journal of Business Ethics, Vol. 121, No. 4, pp.559-576.

Goss, A. and Roberts, G.S. (2011) 'The impact of corporate social responsibility on the cost of bank loan', Journal of Banking and Finance, Vol. 35, Issue 7, pp.1794-1810.

Gregory, A., Tharyan, R. and Whittaker, J. (2014) 'Corporate social responsibility and firm value: disaggregating the effects on cash flow, risk and growth', Journal of Business Ethics, Vol. 124, No. 4, pp.633-657.

Hart, S.L. (1995) 'A natural resource-based view of the firm', Academy of Management Review, Vol. 20, No. 4, pp.986-1014.

Jagannathan, R., Kubota, K. and Takehara, H. (1998) 'Relationship between labor-income risk and average return: empirical evidence from the Japanese stock market', Journal of Business, Vol. 71, No. 3, pp.319-347.

Jensen, M.C. (2001) 'Value maximization, stakeholder theory, and the corporate objective function', Journal of Applied Corporate Finance, Vol. 14, No. 3, pp.38-21. 
Jiao, Y. (2010) 'Stakeholder welfare and firm value', Journal of Banking and Finance, Vol. 34, No. 10 , pp.2549-2561.

Kubota, K. and Takehara, H. (2007) 'Effects of tax rate changes on the cost of capital: case of Japanese firms', Finanz Archiv/Public Finance Analysis, Vol. 63, No. 2, pp.163-185.

Lopatta, K. and Kaspereit, T. (2014) 'The world capital markets' perception of sustainability and the impact of the financial crisis', Journal of Business Ethics, Vol. 122, No. 3, pp.475-500.

Mishra, S. and Modi, S.B. (2013) 'Positive and negative corporate social responsibility, financial leverage, and idiosyncratic risk', Journal of Business Ethics, Vol. 117, No. 2, pp.431-448.

Orlitzky, M. (2008) 'Corporate social performance and financial performance: a research synthesis', in Crane, A., McWilliam, A., Matten, D., Moon, J. and Siegel, D.S. (Eds.): The Oxford Handbook of Corporate Social Responsibility, pp.113-136, Oxford University Press.

Orlitzky, M. and Benjamine, J. (2001) 'Corporate social performance and firm risk; a meta analytic view', Business and Society, Vol. 40, No. 4, pp.369-396.

Orlitzky, M., Schmidt, F.L. and Rynes, S.L. (2003) 'Corporate social and financial performance: a meta-analysis', Organization Studies, Vol. 24, No. 3, pp.403-411.

Perrini, F., Russo, A., Tancati, A. and Vurro, C. (2011) 'Deconstructing the relationship between corporate social and financial performance', Journal of Business Ethics, Vol. 102, No. 1, Supplement, pp.59-76.

Petersen, M.A. (2009) 'Estimating standard errors in finance panel data sets: comparing approaches', Review of Financial Studies, Vol. 22, No. 1, pp.435-480.

Russo, M. and Fouts, P.A. (1997) 'A resource-based perspective on corporate environmental performance and profitability', Academy of Management Journal, Vol. 40, No. 3, pp.534-559.

Salama, A., Anderson, K. and Toms, J.S. (2011) 'Does community and environmental responsibility affect firm risk? Evidence from UK panel data 1994-2006', Business Ethics: A European Review, Vol. 20, No. 2, pp.192-204.

Scholtens, B. and Zhou, Y. (2008) 'Stakeholder relations and financial performance', Sustainable Development, Vol. 16, No. 3, pp.213-232.

Schreck, P. (2011) 'Reviewing the business case for corporate social responsibility: new evidence and Analysis', Journal of Business Ethics, Vol. 103, No. 2, pp.167-188.

Schuler, D.A. and Cording, M. (2006) 'A corporate social performance-corporate financial performance behavioral model for consumers', Academy of Management Review, Vol. 31, No. 3, pp.540-558.

Smith, N.C. (2008) 'Consumers as drivers of corporate social responsibility', in Crane, A., McWilliams, A., Matten, D., Moon, J. and Stiegel, D.S. (Eds.): The Oxford Handbook of Corporate Social Responsibility, pp.281-302.

Surroca, J.J., Tribo, A. and Waddock, S. (2010) 'Corporate responsibility and financial performance: the role of intangible resources', Strategic Management Journal, Vol. 31, No. 5, pp.463-490.

Suto, M. and Takehara, H. (2014) Corporate Social Performance and Foreign Ownership: Evidence From Japanese Firms, Waseda University Institute of Finance, Working Paper Series, WIF-14-003.

Suto, M. and Toshino, M. (2005) 'Behavioural biases of Japanese institutional investors: fund management and corporate governance', Corporate Governance: An International Review, Vol. 13, No. 4, pp.466-477.

Turban, D.B. and Greening, D.W. (1997) 'Corporate social performance and organizational attractiveness to prospective employers', Academy of Management Journal, Vol. 40, No. 3, pp.658-672.

Van Beurden, P. and Gossling, T. (2008) 'The worth of values - a literature review on the relation between social and financial performance', Journal of Business Ethics, Vol. 82, No. 2, pp.407-424. 
Wolf, J. (2014) 'The relationship between sustainable supply chain management, stakeholder pressure and corporate sustainability performance', Journal of Business Ethics, Vol. 119, No. 3, pp.317-328.

\section{Notes}

1 According to research produced by Teikoku Databank Limited, over 24,000 Japanese companies (1.7\% of all Japanese companies) are over one hundred years old as of September 2012. These mature companies represent $3.7 \%$ of all firms in the retail industry and $3.5 \%$ of all firms in the manufacturing industry. The average age of all Japanese companies is 35.6 years.

2 This database is also used in Ajward and Takehara (2014) which investigates the relationship between CSR activities and financial constraints of Japanese firms.

3 The earliest data from the CSR database were from 2006 but the form of the questionnaire was significantly revised in 2007. Toyo Keizai Incorporated sent the questionnaire to the firms in the beginning of July and retrieved responses by the end of September.

4 Fama and French (1992) show that standard CAPMs cannot explain cross-sectional variation in returns for US stocks. This trend was also supported by Japanese data in Jagannathan et al.'s (1998) report that standard CAPM poorly estimates cross-sectional variation in stock returns and that conventional beta is sometimes negatively related to excess return on Japanese stocks. Therefore, we do not use standard CAPM as a benchmark pricing model in this study.

5 To compute ROS, ROE, ROA, and CFOTA, we use data drawn from firms' financial statements in the past five years. To compute GSLS and GTA, we use data from the past six years because an additional year is necessary to compute growth rates. To compute HRET and Alpha, we use stock returns from the 60-month range between October of year $t-5$ and September of year $t$. We use this range because firms sent their questionnaires back to Toyo Keizai Incorporated at the end of September.

6 Suto and Takehara (2014) constructed their CSP database based on the annual CSR questionnaire survey administered by Toyo Keizai Incorporated. Toyo Keizai Incorporated has conducted nine annual surveys on CSR since 2005; however, Suto and Takehara (2014) exclude the 2005 and 2006 surveys because the questionnaire changed significantly thereafter.

7 We use the definition of sectors proposed and used in Kubota and Takehara (2007).

8 The sector definitions are the same as in Table 1.

9 Because we are using short panel data in this research, we employ a regression model with sector dummy and year dummy variables instead of a two-way fixed effects model to avoid a large decrease in the degree of freedom.

10 We conducted the Wu-Hausman's test for endogeneity and Sargan's over-identification test before the two-stage least-squares analysis. The results of these tests are available upon request from the authors. In most cases, the null hypothesis in the Wu-Hausman's test is not rejected.

11 We first ran an ordinary least square (OLS) regression and considered observations with standardised residuals greater than 3.0 or smaller than -3.0 to be outliers. In the subsequent two-stage LS analysis, we also excluded these firm-year observations in the panel data.

12 Standard errors are corrected by the two-way cluster error correction method proposed by Petersen (2009).

13 In Table 5, we only show the slopes for the CSP indices because of a space constraint. Regression results are available upon request. 
Table A1 Adopted questions from CSR survey of Toyo Keizai CSR database

\begin{tabular}{|c|c|c|}
\hline \multicolumn{2}{|c|}{ Evaluation point } & Weights \\
\hline \multicolumn{2}{|c|}{ Employee relations $(E M P)$} & 29.478 \\
\hline 1 & Ratio of female employees to total employees & -0.192 \\
\hline 2 & Ratio of female managers to total managers & -0.304 \\
\hline 3 & Ratio of physically handicapped employees to total employees & -0.282 \\
\hline 4 & Ratio of old employees ( 60 years old and over) to total employees & -0.252 \\
\hline 5 & Average years of continuous employment & -0.162 \\
\hline 6 & Labour turnover rate & -0.349 \\
\hline 7 & Average salary for a 30 years old & -0.312 \\
\hline 8 & Overtime hours & -0.328 \\
\hline 9 & Overtime wage per hour & -0.341 \\
\hline 10 & Rate of paid holidays taken & -0.344 \\
\hline 11 & Frequency rates of industrial injuries & -0.223 \\
\hline 12 & $\begin{array}{l}\text { Flexible work arrangement (flex-time, short-time working, on-site child care, } \\
\text { etc.) }\end{array}$ & -0.219 \\
\hline 13 & Incentive program (internal venture, bonus plan, education program, etc.) & -0.208 \\
\hline \multicolumn{2}{|c|}{ Social contribution (SC) } & 51.736 \\
\hline 1 & $\begin{array}{l}\text { Comprehensive evaluation (CSR department, director in charge, CSR } \\
\text { document etc.) }\end{array}$ & -0.438 \\
\hline 2 & Corporate ethics (guidelines, business ethics document, etc.) & -0.263 \\
\hline 3 & Department of social actions & -0.703 \\
\hline 4 & Social expenditure per employee & -0.430 \\
\hline 5 & Matching gift and volunteer grant programs & -0.243 \\
\hline \multicolumn{2}{|r|}{ Security of the firm and product safeness (SS) } & 45.279 \\
\hline 1 & $\begin{array}{l}\text { Specialty divisions on investor relations, consumer affairs, cooperation with } \\
\text { NPO. }\end{array}$ & -0.268 \\
\hline 2 & Whistle-blower policy & -0.111 \\
\hline 3 & Specialty department for managing quality and safety of products and services & -0.910 \\
\hline 4 & Ratio of domestic business offices with ISO9000 certification & -0.212 \\
\hline 5 & Ratio of foreign business offices with ISO9000 certification & -0.206 \\
\hline \multicolumn{2}{|r|}{ Internal governance and risk management (IG) } & 35.766 \\
\hline 1 & $\begin{array}{l}\text { Comprehensive evaluation (whistle-blower protection, CSR manual, complaint } \\
\text { DB, etc.) }\end{array}$ & -0.151 \\
\hline 2 & Existence/non-existence of compliance department & -0.436 \\
\hline 3 & Existence/non-existence of CIO & -0.594 \\
\hline 4 & Existence/non-existence of CFO & -0.620 \\
\hline 5 & Information systems (security policy, internal/external auditing, etc.) & -0.204 \\
\hline 6 & $\begin{array}{l}\text { Comprehensive evaluation (fair trade, compliance, closedown in the past } \\
3 \text { years, etc.) }\end{array}$ & -0.093 \\
\hline
\end{tabular}

Note: Numbers in the column named 'weights' are the contribution rate (in \%) of CSP dimensional indices and loadings of first principal component as of September 2011. 
Table A1 Adopted questions from CSR survey of Toyo Keizai CSR database (continued)

\begin{tabular}{llc}
\hline Evaluation point & Weights \\
\hline \multicolumn{2}{l}{ Environment preservations (ENV) } & 49.216 \\
1 & Environmental planning department, director in charge of environmental affairs, & -0.496 \\
& etc. & -0.587 \\
2 & Environmental accounting, disclosure and auditing. & -0.427 \\
3 & Ratio of environment related business to total revenue & -0.466 \\
4 & Promotion of procurement of eco-friendly goods and services & -0.036 \\
5 & Ecolabelling (ISO14020 series, etc.) & -0.090 \\
6 & Environment related compliance (environmental disasters, law violation, etc.) & \\
\hline
\end{tabular}

Note: Numbers in the column named 'weights' are the contribution rate (in \%) of CSP dimensional indices and loadings of first principal component as of September 2011.

Table A2 Definition of profitability/risk measures

\begin{tabular}{|c|c|c|c|}
\hline Variable name & \multicolumn{2}{|c|}{ Firms' profitability measures and their definitions } & Data period \\
\hline ROS & Return on sales & $=\left(\right.$ Net $\left._{\text {Income }}\right) /\left(\right.$ Sales $\left._{t}\right)$ & $\begin{array}{l}\text { Past } 5 \text { years } \\
\text { average }\end{array}$ \\
\hline ROE & Return on equity & $\begin{aligned}= & \left(\text { Net Income }_{t}\right) / \\
& \left(\text { Book Value }_{t-1}\right)\end{aligned}$ & $\begin{array}{l}\text { Past } 5 \text { years } \\
\text { average }\end{array}$ \\
\hline ROA & Return on assets & $\left.\begin{array}{l}=\left(\text { Net Income }_{t}\right) / \\
(\text { Total Assets } \\
t-1\end{array}\right)$ & $\begin{array}{l}\text { Past } 5 \text { years } \\
\text { average }\end{array}$ \\
\hline CFOTA & $\begin{array}{l}\text { Cash-flow to total } \\
\text { assets }\end{array}$ & $\begin{array}{l}\quad=\left(\text { Cash }_{\text {-flow from }}\right. \\
\left.\text { Operations }_{t}\right) /\left(\text { Total Assets }_{t-1}\right)\end{array}$ & $\begin{array}{l}\text { Past } 5 \text { years } \\
\text { average }\end{array}$ \\
\hline GSLS & Growth rate of sales & $=\left(\right.$ Sales $\left._{t}\right) /\left(\right.$ Sales $\left._{t-1}\right)-1$ & $\begin{array}{l}\text { Past } 5 \text { years } \\
\text { average }\end{array}$ \\
\hline GTA & $\begin{array}{l}\text { Growth rate of total } \\
\text { assets }\end{array}$ & $\begin{array}{l}=\left(\text { Total Assets }_{t}\right) / \\
\left(\text { Total Assets }_{t-1}\right)-1\end{array}$ & $\begin{array}{l}\text { Past } 5 \text { years } \\
\text { average }\end{array}$ \\
\hline HRET & $\begin{array}{l}\text { Historical stock } \\
\text { return }\end{array}$ & $\begin{array}{l}\text { Historical average of realised } \\
\text { monthly return }\end{array}$ & $\begin{array}{l}\text { Past } 60 \text { months } \\
\text { data }\end{array}$ \\
\hline Alpha & Jensen's alpha & $\begin{array}{l}\text { Computed based on } \\
\text { Fama and French (1993) }\end{array}$ & $\begin{array}{l}\text { Past } 60 \text { months } \\
\text { data }\end{array}$ \\
\hline Variable name & \multicolumn{3}{|c|}{ Firms' risk measures and their definition } \\
\hline ROSSD & \multicolumn{3}{|c|}{ Past 5 year standard deviation of return on sales (ROS) } \\
\hline ROESD & \multicolumn{3}{|c|}{ Past 5 year standard deviation of return on equity (ROS) } \\
\hline ROASD & \multicolumn{3}{|c|}{ Past 5 year standard deviation of return on assets (ROA) } \\
\hline CFOSD & \multicolumn{3}{|c|}{ Past 5 year standard deviation of cash-flow to total assets (CFOTA) } \\
\hline GSLSSD & \multicolumn{3}{|c|}{ Past 5 year standard deviation of growth rate of sales (GSLS) } \\
\hline GTASD & \multicolumn{3}{|c|}{ Past 5 year standard deviation of growth rate of total assets (GTA) } \\
\hline HVOL & \multicolumn{3}{|c|}{ Past 60 months historical volatility } \\
\hline BHML & \multicolumn{3}{|c|}{$\begin{array}{l}\text { Past } 60 \text { months HML beta computed based on Fama and French } 3 \text { factor } \\
\text { model. }\end{array}$} \\
\hline
\end{tabular}

